\begin{abstract}
"Mircea cel Batran" Naval Academy Scientific Bulletin, Volume XIX - 2016 - Issue 1
Published by "Mircea cel Batran" Naval Academy Press, Constanta, Romania /I The journal is indexed in:

PROQUEST / DOAJ / DRJI / JOURNAL INDEX / I2OR / SCIENCE LIBRARY INDEX / Google Scholar / Crossref /

Academic Keys I ROAD Open Access / OAJI / Academic Resources / Scientific Indexing Services / SCIPIO
\end{abstract}

\title{
EFFECTS OF LOW FREQUENCY ELECTROMAGNETIC FIELD ON THE HUMAN BODY
}

\author{
Petrică POPOV ${ }^{1}$ \\ Vasile DOBREF ${ }^{2}$ \\ Florenţiu DELIU ${ }^{3}$ \\ Paul BURLACU 4 \\ 1. Lecturer PhD Naval Academy "Mircea cel Batran", Constanța, petrica.popov@anmb.ro \\ 2. Professor PhD eng. Naval Academy “Mircea cel Batran”, Constanța, vasile.dobref@anmb.ro \\ 3. Lecturer PhD eng.Naval Academy "Mircea cel Batran", Constanta, florentiu.deliu@anmb.ro \\ 4. Lecturer PhD eng.Naval Academy “Mircea cel Batran”, Constanța, paul.burlacu@anmb.ro
}

\begin{abstract}
International standardization institutions, which play an important role in assessing the effects of the field and determining the need to take protective measures for the human factor, developed safety standards on human exposure to electromagnetic field, differentiated for electric and magnetic fields of low frequency ( near fields), as well as to electromagnetic radiation fields (far fields).

Until recently, many studies has shown that the main harmful effect on the human body was produced by high frequency electromagnetic field, but in recent years, more and more information also reveals that the serious damage can be caused by low frequency electric and magnetic fields. These low-frequency electromagnetic fields interact with human tissue causing harmful effects, the degree of destruction depending on factors such as: intensity, frequency, energy field level and duration of exposure.
\end{abstract}

Keywords: protective measures; near field

\section{Introduction}

Whether 20 years ago it is considered to be harmful for the body, especially radio-frequency fields (from a few tens of $\mathrm{MHz}$ to hundreds of $\mathrm{MHz}$ ) and microwaves (from $300 \mathrm{MHz}$ to 300 $\mathrm{GHz}$ ), today we know that low frequency fields electrical and magnetic - are particularly dangerous because they can induce voltage in human tissues of the order millivolts, disrupting cellular metabolism over time.

Since the mid of ' 70 , international standardization bodies, civilian and military, develop regulations and safety standards of personnel working in electromagnetic hazardous conditions. Among the most important mention IRPA (International Radiation Protection Association), WHO (Word Health Organization), IEEE-SA (Institute of Electrical and Electronics Engineers Standards Association), ICNIRP (International Commission on Non-lonizing Radiation Protection). It is important to note that international recommended to take measures to protect personnel even while the results of scientific research does not present a high degree of certainty.

Safety standards aimed at both exposure to electric and magnetic fields of low frequency and radio frequency fields and microwave, establishing maximum permissible exposure levels correlated with minimum thresholds for adverse effects; to which are added a safety factor.

\section{Electromagnetic field parametershuman cells and biological response}

The electromagnetic field is used to summarize the whole field, which includes "electric," "magnetic" and combined "electromagnetic" effects. Electric field (EF) involves a current that can be either direct (DC) or alternating (AC). Electric current units are measured in amperes (A). Electrical potential differences are measured in volts (V). Units of magnetic flux density (intensity) are measured in either Gauss (G), or Tesla (T), which is $10,000 \mathrm{G}$

Faraday's law of induction and Maxwell's equations explain how an EMF is generated. A static electric field (SEF) is generated by a static charged particle (q). The electric field (or E component of an EMF) exists whenever charge (q) is present. The strength of this field (E) is measured in volts per meter [V/m], and expressed as intensity of field. Magnetic field (or $\mathrm{M}$ component of an EMF) arises from current flow. The Tesla (or Gauss) is mainly used to express the flux density or field strength produced by the MF. Both EFs and MFs are generated if a charged particle moves at a constant velocity. In general we can say that a change in the EF creates an $M F$, and any change in the MF creates an EF.

Depending on the main frequency of the timevarying fields, it is customary to characterize fields as static, extremely low frequency, very low frequency fields, radio frequency fields and microwave fields. 


\begin{abstract}
"Mircea cel Batran" Naval Academy Scientific Bulletin, Volume XIX - 2016 - Issue 1
Published by "Mircea cel Batran" Naval Academy Press, Constanta, Romania /I The journal is indexed in: PROQUEST / DOAJ / DRJI / JOURNAL INDEX / I2OR / SCIENCE LIBRARY INDEX / Google Scholar / Crossref /

Academic Keys / ROAD Open Access / OAJI / Academic Resources / Scientific Indexing Services / SCIPIO
\end{abstract}

The definition of different frequency bands for low frequency fields are not universally agreed upon, but one possible characterization is as follows:

- Static fields (SEF; SMF) - $0-3 \mathrm{~Hz}$;

- $\quad$ Extreme low frequency- ELF- $3-3000 \mathrm{~Hz}$;

- Very low frequency - VLF-3 - $300 \mathrm{kHz}$;

- $\quad$ Radio frequency - RF- $0.3-300 \mathrm{MHz}$;

- $\quad$ Microwaves $0.3-300 \mathrm{GHz}$.

Electromagnetic waves are transverse waves and component having electric and magnetic component, the electric and magnetic vectors being perpendicular to each other and both to the direction of propagation. From the point of view of the wave spectrum of electromagnetic radiation extends from radio waves characterized by low frequencies and long wavelengths larger $(\mathrm{km})$ to the high-energy radiation with higher frequencies and smaller wavelengths. This interaction between electric and magnetic fields at high frequency of oscillation, represent the fact that they are mutually coupled.

EMF can affect biochemical reactions and the behavior of charged molecules near cell membranes. MF can influence cell behavior by [7]:

- $\quad$ exerting force on moving charge carriers such as ions;

- $\quad$ generating electric fields in conductive substances;

- changing the rate of diffusion across membranes;

- distorting bond angles, which affects protein structure binding, and therefore macromolecule synthesis [10].

Unlike EF, which are shielded by the high dielectric properties of the cell membrane, magnetic gradients penetrate deeper through layers of living tissue [8], acting directly on cell organelles. Pulsing the EMF causes a rise and fall in ion fluxes, whereby changes in the membrane potential cause an inward current flow resulting in hyperpolarization of its potential [9].

Because a cell's diameter is much larger than the membrane thickness, it is reasonable to ignore the curvature of the cell and think of it as a charged capacitor with a capacitance of approximately $2 \mu \mathrm{F}$ per $\mathrm{cm}^{2}$ of membrane area [11]. The differences in various ion concentrations on either side of the membrane can result in a new voltage of between 70 and $80 \mathrm{mV}$ across the membrane. The sheet of negative charge on the intracellular side of the membrane and the sheet of positive charge on the extracellular side forms a capacitor. This voltage difference keeps weaker EF from entering the cell.

For example a typical high-voltage transmission line creates a ground level electric field on the order of $100 \mathrm{~V} / \mathrm{cm}$ and $1 \mathrm{Ga}$. Background power frequency fields in a typical office are about $0.01-0.10 \mathrm{~V} / \mathrm{cm}$ and $0.01-0.10 \mathrm{Ga}$. Numerous investigators have reported biological effects in animals and human beings following exposure to such fields. Prediction of whether specific effects will occur in the general population as a consequence of exposure to the fields of various electrical devices depends in each instance on an evaluation of the nature and extent of the exposure and the results of the laboratory research.[5]

Numerous studies have shown some links between low frequency electromagnetic field values and the possible occurrence of diseases like [4]:

- Cancer. Epidemiological studies of cancer have focused on two primary populations: children in residential settings and adults in occupational settings. The main cancers associated with EMF exposure are leukemia, nervous system tumors and, to a lesser extent lymphoma among children; and leukemia, nervous system tumors, and breast cancer among adults.

- Reproduction. Adverse pregnancy outcomes, including miscarriages, still births, congenital deformities, have been associated with maternal occupational exposure to electromagnetic fields (Goldhaber et al. 1988) as well as residential use of electric blankets, heated waterbeds, conductive heating elements in bedroom ceilings (Wertheimer and Leeper 1986, 1989, Hatch et al. 1998).

- Depression. Several lines of evidence suggest that depression is associated with and may be induced by exposure to electromagnetic fields. Epidemiological studies have found higher ratios of depression-like symptoms (Poole et al. 1993) and higher rates of suicide (Reichmanis et al. 1979) among people living near transmission lines.

- Alzheimer's disease. In contrast to cancers, very few studies have examined the association between occupational EMF exposure and Alzheimer's disease. One case-control study by Sobel et al. (1995) included 3 independent clinical series of non-familial Alzheimer's disease in Finland (2 series) and California, USA (1 series). Non-familial Alzheimer's was selected to minimize the genetic influences in the etiology of this disease. A total of387 cases and 475 control were included in the combined series and were classified into tw EMF categories (medium/high and low exposure in primary occupations). 
"Mircea cel Batran" Naval Academy Scientific Bulletin, Volume XIX - 2016 - Issue 1

Published by "Mircea cel Batran" Naval Academy Press, Constanta, Romania // The journal is indexed in: PROQUEST / DOAJ / DRJI / JOURNAL INDEX / I2OR / SCIENCE LIBRARY INDEX / Google Scholar / Crossref /

Academic Keys / ROAD Open Access / OAJI / Academic Resources / Scientific Indexing Services / SCIPIO

- Amyotrophic Lateral Sclerosis (ALS). Several studies link EMF exposure to amyotrophic lateral sclerosis (ALS). Three studies have reported a statistically significant increase in ALS, with a relative risk from 1.3 to 3.8 , for electric utility workers (Deapen and Hendersen 1986, Savitz et al. 1998a,b, Johansen and Olsen 1998). The California EMF Program classifies EMFs as possibly causal agents in ALS. Both Alzheimer's disease and ALS are neurodegenerative diseases.

Biological effects of exposure to low frequency electromagnetic fields have been reviewed by the International Agency for Research on Cancer (IARC), ICNIRP, and the World Health Organization (WHO) (IARC 2002; ICNIRP 2003a; WHO 2007a)

3. ICNIRP-Guidelines for exposure to low electric and magnetic fields

Currently, according to ICNIRP-Guidelines for exposure to time limiting electric and magnetic fields varying $(1 \mathrm{~Hz}-100 \mathrm{kHz}), 2010$, the commercial frequency $50 / 60 \mathrm{~Hz}$ limits for exposure criteria used is the electric field inside the body. For the assessment of exposure to frequencies below $100 \mathrm{kHz}$ is recommended electric field strength of the tissues because the physical quantity is correlated with biological effects and itself is linked to the current density.

For higher frequencies are used SAR (Specific Absorption Rate) which correlates with the square of the electric field strength in the tissue. SAR is the rate at which the wave energy is absorbed in a tissue mass $\mathrm{m}$ and is measured in watts / $\mathrm{kg}$ (W/ $\mathrm{kg}$ ). This physical quantity varies punctually in the body, because the electric field changes with body position and conductivity of tissue is different.

In Tables 1 and 2 are shown the limits of electric and magnetic field strenght and magnetic flux density and for controlled and uncontrolled environments.

Table 1 - Reference levels for occupational exposure to time-varying electric and magnetic fields (unperturbed RMS values)

\begin{tabular}{|l|l|l|l|}
\hline $\begin{array}{l}\text { Frequency } \\
\text { range }(\mathrm{Hz})\end{array}$ & $\begin{array}{l}\text { E-field } \\
\text { strength } \\
(\mathrm{kV} / \mathrm{m})\end{array}$ & $\begin{array}{l}\text { Magnetic } \\
\text { field } \\
\text { strength } \\
(\mathrm{A} / \mathrm{m})\end{array}$ & $\begin{array}{l}\text { Magnetic } \\
\text { flux density } \\
\mathrm{B}(\mathrm{T})\end{array}$ \\
\hline $1 \mathrm{~Hz}-8 \mathrm{~Hz}$ & 20 & $1.63 \times 10^{5} / \mathrm{f}^{2}$ & $0.2 / \mathrm{f}^{2}$ \\
\hline $8 \mathrm{~Hz}-25 \mathrm{~Hz}$ & 20 & $2 \times 10^{4} / \mathrm{f}$ & $2.5 \times 10^{-2} / \mathrm{f}$ \\
\hline $25 \mathrm{~Hz}-300 \mathrm{~Hz}$ & $5 \times 10^{2} / \mathrm{f}$ & $8 \times 10^{2}$ & $1 \times 10^{-3}$ \\
\hline
\end{tabular}

$\mathrm{f}-$ in $\mathrm{Hz}$

Table 2 - Reference levels for general public exposure to time-varying electric and magnetic fields (unperturbed RMS values)

DOI: 10.21279/1454-864X-16-I1-044

(C) 2015. This work is licensed under the Creative Commons Attribution-Noncommercial-Share Alike 4.0 License.

\begin{tabular}{|l|l|l|l|}
\hline $\begin{array}{l}\text { Frequency } \\
\text { range }(\mathrm{Hz})\end{array}$ & $\begin{array}{l}\text { E-field } \\
\text { strength } \\
(\mathrm{kV} / \mathrm{m})\end{array}$ & $\begin{array}{l}\text { Magnetic } \\
\text { field } \\
\text { strength } \\
(\mathrm{A} / \mathrm{m})\end{array}$ & $\begin{array}{l}\text { Magnetic } \\
\text { flux density } \\
\mathrm{B}(\mathrm{T})\end{array}$ \\
\hline $1 \mathrm{~Hz}-8 \mathrm{~Hz}$ & 5 & $3.2 \times 10^{4} / \mathrm{f}^{2}$ & $4 \times 10^{2} / \mathrm{f}^{2}$ \\
\hline $8 \mathrm{~Hz}-25 \mathrm{~Hz}$ & 5 & $4 \times 10^{3} / \mathrm{f}$ & $5 \times 10^{-3} / \mathrm{f}$ \\
\hline $25 \mathrm{~Hz}-50 \mathrm{~Hz}$ & 5 & $1.6 \times 10^{2}$ & $2 \times 10^{-4}$ \\
\hline $50 \mathrm{~Hz}-400 \mathrm{~Hz}$ & $2.5 \times 10^{2} / \mathrm{f}$ & $1.6 \times 10^{2}$ & $2 \times 10^{-4}$ \\
\hline
\end{tabular}

$\mathrm{f}-$ in $\mathrm{Hz}$

According to Directive 2004/40 / EC of the European Parliament on the requirements for exposure of personnel to electromagnetic fields, completed 2008/46 / EC, are provided and accepted limits of the electric and magnetic field strength in the human body. Table 3 indicates the field strength limits, the RMS values, and the power density for controlled environments, the continuous exposure of the body (data refer to undisturbed fields).

Table 3 - Limits of the field strength and power density for controlled environments in continuous exposure

\begin{tabular}{|c|c|c|c|c|}
\hline $\begin{array}{c}\text { Frequency } \\
\text { range }(\mathrm{Hz})\end{array}$ & $\begin{array}{c}\text { E-field } \\
\text { strength } \\
\mathrm{E}(\mathrm{V} / \mathrm{m})\end{array}$ & $\begin{array}{c}\text { Magnetic } \\
\text { field } \\
\text { strength H } \\
(\mathrm{A} / \mathrm{m})\end{array}$ & $\begin{array}{c}\text { Magnetic } \\
\text { flux } \\
\text { density B } \\
(\mu \mathrm{T})\end{array}$ & $\begin{array}{c}\text { Contact } \\
\text { currents } \\
\mathrm{I}_{\mathrm{C}}(\mathrm{mA})\end{array}$ \\
\hline $0-1 \mathrm{~Hz}$ & - & $1,63 \times 10^{5}$ & $2 \times 10^{5}$ & 1,0 \\
\hline $1-8 \mathrm{~Hz}$ & 20000 & $1,63 \times 10^{5} / \mathrm{f}^{2}$ & $2 \times 10^{5} / \mathrm{f}^{2}$ & 1,0 \\
\hline $8-25 \mathrm{~Hz}$ & 20000 & $2 \times 10^{4} / \mathrm{f}$ & $2,5 \times 10^{4} / \mathrm{f}$ & 1,0 \\
\hline $0,025-0,82 \mathrm{kHz}$ & $500 / \mathrm{f}$ & $20 / \mathrm{f}$ & $25 / \mathrm{f}$ & 1,0 \\
\hline
\end{tabular}

$f$ - frequency is expressed in the unit of the specified domain; continuous exposure: $t_{\text {exp. }} \geq 6$ minutes

In case of simultaneous exposure of the body to more sources of independent field with various frequencies, evaluation of effective reference levels was done on the principle of accumulation of heat or electrical stimulation effects on the body.

The standard also requires limits for contact current on in a situation where a person touches a large metal object, isolated, located in the field.

Based on the review of the scientific evidence ICNIRP recommends the following limits on exposure:

- Occupational exposures: In the frequency range $10 \mathrm{~Hz}$ to $25 \mathrm{~Hz}$, occupational exposure should be limited to fields that induce electric field strengths in tissue of the head (i.e., the brain and retina) of less than $50 \mathrm{mV} / \mathrm{m}$. These restrictions should also prevent any possible transient effects on brain function. These effects are not considered to be adverse health effects; however, ICNIRP recognizes that they may be disturbing in some occupational circumstances and should be avoided, but no additional reduction factor is applied. At lower frequencies the limit value for 


\begin{abstract}
"Mircea cel Batran" Naval Academy Scientific Bulletin, Volume XIX - 2016 - Issue 1
Published by "Mircea cel Batran" Naval Academy Press, Constanta, Romania // The journal is indexed in: PROQUEST / DOAJ / DRJI / JOURNAL INDEX / I2OR / SCIENCE LIBRARY INDEX / Google Scholar / Crossref /

Academic Keys / ROAD Open Access / OAJI / Academic Resources / Scientific Indexing Services / SCIPIO
\end{abstract}

the induced electric field strength rises in reverse proportion to frequency. At higher frequencies, up to $400 \mathrm{~Hz}$ the limit value rises proportional to frequency. At frequencies in the range $400 \mathrm{~Hz}$ to 3 $\mathrm{kHz}$ occupational exposure should be limited to fields that induce electric field strengths in all parts of the body of less than $50 \mathrm{mV} / \mathrm{m}$ in order to avoid peripheral and central myelinated nerve stimulation.

- General public exposures: in the frequency range $10 \mathrm{~Hz}$ to $25 \mathrm{~Hz}$, general public exposure should be limited to fields that induce electric field strengths in CNS tissue of the head (i.e., the brain and retina) of less than $10 \mathrm{mV} / \mathrm{m}$.
These restrictions should also prevent any possible transient effects on brain function. A reduction factor of 5 has been applied to the phosphene threshold of $50 \mathrm{mV} / \mathrm{m}$ in order to account for uncertainties. Above and below this frequency range, the basic restriction rises. At $1000 \mathrm{~Hz}$ it intersects with basic restrictions that protect against peripheral and central myelinated nerve stimulation. Here, a reduction factor of 10 , with respect to the above mentioned stimulation threshold of $4 \mathrm{~V} / \mathrm{m}$, results in a basic restriction of $400 \mathrm{mV} / \mathrm{m}$; which should be applied to the tissues of all parts of the body.

\title{
CONCLUSIONS
}

Following researches it is obvious that electric and magnetic fields do affect living systems. These effects vary with individual sensitivities and it can occur at low frequencies and low intensities of electromagnetic field.

In order to manage the risk of EMF it is needed to understand the parameters of exposure that are biologically important to identify biological parameters and the mechanisms responsible for those.

Despite the fact that EMF interactions is complex, recent studies in this area provided us a novel view of how living systems work.

\section{BIBLIOGRAPHY}

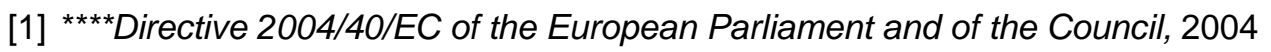

[2] ${ }^{* \star * *}$ Guidelines for limiting exposure to time-varying electric, magnetic, and electromagnetic fields (up to $300 \mathrm{GHz}$ )- ICNIRP Guidelines

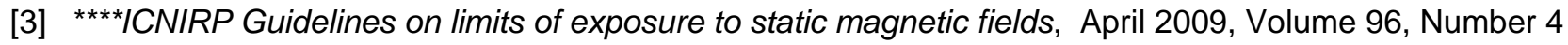

[4] Magda HavasBiological Effects of Low Frequency Electromagnetic Fields - D. Clements-Croome (Ed.). 2004. Electromagnetic Environments and Health in Buildings. Spon Press, London, 535 pp.

[5] Andrew A. Marino and Robert O. Becker - Biological effects of extremely low frequency electric and magnetic fields - PHYSIOLOG1CAL CHEMISTRY and PHYSICS, Volume 9, Number 2, 1977

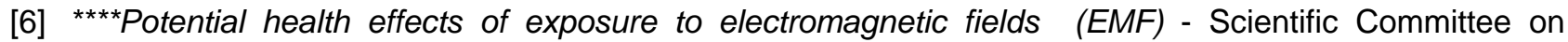
Emerging and Newly Identified Health Risks, 27 January 2015

[7] Christina L. Ross, Mevan Siriwardane Graça Almeida-Porada, Christophe r D. Porada, Peter Brink, George J.Christ, Benjamin S.Harrison- The effect of low-frequency electromagnetic field on human bone marrow stem/progenitor cell differentiation, Science Direct, Stem Cell Research (2015) 15 ,96- 108

[8] [8] R.H. Funk, T.K. MonseesEffects of electromagnetic fields on cells: physiological and therapeutical approaches and molecular mechanisms of interaction, Cells Tissues Organs, 182 (2006), pp. 59-78

[9] [9] B. Alberts, A. Johnson, J. Lewis, M. Raff, K. Roberts, K. WalterMolecular Biology of the Cell (4th edition), Garland Science, New York (2002), pp. 528-530

[10] M.E. BarnothyBiological Effects of Magnetic Fields, Plenum Press 2, NY (1969)

[11] B. Hillelonic Channels of Excitable Membranes (Second Edition), Sunderland, MA, Sinauer Associates Inc (1992) 